\title{
Patients' Perception at the Moment of Disclosure of Cancer Diagnosis
}

\author{
Bruno Vilas Boas Dias ${ }^{1, ~ *, ~ C r i s t i a n e ~ G r a s s i a ~ S i l v a ~}{ }^{2}$, Luana de Carvalho Valentim da Costa ${ }^{2}$, \\ Luana Iris Nunes Romero ${ }^{2}$, Admilson Soares de Paula ${ }^{3}$ \\ ${ }^{1}$ Department of Nursing at Padre Anchieta University Center, Jundiaí-SP, Brazil and Campo Limpo Paulista Faculty, Campo Limpo Paulista- \\ SP, Brazil \\ ${ }^{2}$ Department of Nursing, Padre Anchieta University Center, Jundiaí-SP, Brazil \\ ${ }^{3}$ Department of Nursing at Padre Anchieta University Center, Jundiaí-SP and Campo Limpo Paulista Faculty, Campo Limpo Paulista-SP, \\ Brazil
}

\section{Email address:}

bruno.dias@anchieta.br(B.V.B. Dias), cristhianegrassia@yahoo.com.br(C.G. Silva), valentimlu@hotmail.com(L.C. V. Costa), luana_iris@hotmail.com(L.I.N.Romero),ade.soares@hotmail.com.br(A.S.Paula)

${ }^{*}$ Corresponding author

\section{To cite this article:}

Bruno Vilas Boas Dias, Cristiane Grassia Silva, Luana de Carvalho Valentim da Costa, Luana Iris Nunes Romero, Admilson Soares de Paula. Patients' Perception at the Moment of Disclosure of Cancer Diagnosis. American Journal of Health Research.

Vol. 6, No. 2, 2018, pp. 51-55. doi: 10.11648/j.ajhr.20180602.13

Received: September 25, 2017; Accepted: October 6, 2017; Published: March 28, 2018

\begin{abstract}
Cancer is a disease characterized by abnormal cell formation and division, a mutation linked to several external and internal factors and related to habits and cultures. The objective of this study was to know the perception of patients of the Brazilian Association of People with Cancer (ABRAPEC) from Jundiaí-SP at the moment of disclosure of cancer diagnosis. This was a qualitative, exploratory and descriptive study, based on the theory of Social Representations, following the guidelines of the Discourse of the Collective Subject. The sample was composed of 30 ABRAPEC users who answered two questionnaires, one with five questions on biosocial aspects, and another with one question regarding the main objective of the study. The central ideas of the participants regarding the feelings at disclosure of cancer diagnosis were: "fear"; "sadness"; "death"; "normal"; "guilt"; "fright" and "suicide". The central ideas, for the most part, showed that the news of cancer represents feelings of hopelessness and even death.
\end{abstract}

Keywords: Neoplasms, Oncology, Nursing Care

\section{Introduction}

Cancer is characterized by a disordered growth of cells that invade tissues and organs forming malignant tumors. Cell migration to other tissues and organs may occur when they detach from the primary tumor, through blood and lymphatic stream reaching other regions of the body, characterizing metastasis [1].

As these cells have a rapid division, they tend to be very aggressive and uncontrollable, determining the formation of tumors (accumulation of cancer cells) or malignant neoplasms. On the other hand, a tumor is benign when a localized mass of cells multiply slowly and resemble their original tissue, rarely posing a risk to life [1].
The etiology of cancer is complex, with external factors (food and sexual habits, smoking, medication, alcoholism, solar radiation and occupational factors) interrelating with internal factors (bad habits and genetically predetermined organisms), as they are directly linked with the form of reaction against a cellular aggression of high malignancy. Approximately $80 \%$ to $90 \%$ of cancers are associated with socio-environmental factors [2].

A total of 576,000 new cases of cancer are estimated for $2014 / 2015$. These are represented by prostate $(69,000)$, stomach $(20,000)$, cervix $(15,000)$, female breast $(75,000)$, colon and rectum $(33,000)$ and skin $(182,000)$ cancer [3].

Health professionals have a relevant role in the lives of these patients and their families as supporters and even 
facilitators, through the provision of guidance about living with the disease, adverse reactions to treatment and maintenance of self-care, and especially through the hosting of these patients. Besides the usual and standardized interventions for cancer treatment, health professionals can use information from the literature and from previous experiences to help patients their families, always respecting ethical and moral standards not only during the recovery, but since the very moment of disclosure of the diagnosis $[4,5]$.

The National Cancer Institute has launched a book on "Disclosure of difficult news: sharing health care challenges" highlighting the advancement of technologies and treatments, the aging of the population and the need to humanize professionals with a view to enhance the quality of life of patients.

In a reflection on what we call bad news, it is understood that this is any element of external reality that provokes the awareness of this reality and its autonomous characteristic in relation to the wishes of the sender and receiver of the news [6].

Usual bad news in medicine and in life in general are related to aging with its consequent functional and psychological losses, illness and death. They are bad news, therefore, because they wake us up to a reality that we do not want to see. And they represent bad news for both the recipient and the health professionals, because of three basic reasons, combined to varying degrees in each professional: health professionals are persons who also wants to escape from this reality, regardless of their choice of career; the own choice of career holds an idea or intention, more or less conscious, of being able to overcome the reality of human frailty; and facing these realities along with a patient can be experienced as an attack on the feelings of omnipotence often cultivated by health professionals (related to the second item above) and can consequently prompt feelings of helplessness, failure, and frustration [7].

Thus, despite the preparation during undergraduate training, it is still urgent to evaluate our role in giving the bad news, and one of the ways to reach such a conclusion can be start by understanding the perceptions of the patients we assist and who we will eventually have to approach with bad news [8].

The objective of this study was therefore to know the perception of patients of the Brazilian Association of People with Cancer (ABRAPEC) from Jundiaí, São Paulo (SP) at the moment of disclosure of cancer diagnosis.

\section{Method}

This was a qualitative, exploratory and descriptive study, based on the theory of Social Representations, following the guidelines of the Discourse of the Collective Subject.

Nursing has been using the assumptions of the Theory of Social Representations since the 1980s, seeking to understand the psychosocial aspects that raise several research objects on which the theory focuses.

In this way, the Theory of Social Representations presents great adherence to the objects of studies in the nursing area, once this method is able to apprehend the most subjective aspects that permeate the problems inherent in this area. The representation is not a copy of reality, a reflection of the outside world; it is rather its translation, its re-elaboration by the subject, who is an active subject [9].

Representation is always social, not only because it is socially elaborated, but because it is elaborated with categories of language or codes of interpretation provided by society and by the social practice of the subject, with its norms and ideologies that flow from it.

Another aspect of the Theory of Social Representations relates to the foundations of social representations necessary to differentiate two approaches: social representations as a socially structured field and as structuring nucleus of action [10].

As a socially structured field, they imply knowing the individual experiences as arising from the social reality in which the subject is immersed; this reality is manifested in the form of delimited "social fields": family, neighborhood, professional category. It implies that the social conditions in which these subjects are inserted determine their representations and the discourses that convey them. From the point of view of the structuring nucleus of actions, they consider the subjects to be the producer of meaning, that is, the ones who expresses in their representations the sense they give to their experience in the social world [11].

In short, SRs are a form of practical knowledge - commonsense knowledge - whose purpose is to establish an order that allows individuals to orient themselves in their world and to dominate it, and to enable communication between peers in a given group. They serve to know and describe the meanings of the opinions of users of the Brazilian Association of Assistance as People with Cancer [9, 12].

The option for the qualitative approach is the best path, and the Discourse of the Collective Subject was the chosen method for the construction of meanings, allowing the approximation with the phenomenon under study. The discourse of the collective subject consists in the reunion of several individual discourses issued as a response to a given research question in a single discourse-synthesis. The individual discourses are provided by socially and institutionally equivalent subjects, or subjects that are part of the same organizational culture and of a homogeneous social group, insofar as the individuals who belong to this group occupy the same or neighboring positions in a given social field.

The discourse of the collective subject is therefore a way of directly expressing the social representation of a given subject/participant [13].

The sample was composed of 30 ABRAPEC users from the city of Jundiaí/SP, duly registered and randomly selected. They answered two questionnaires prepared by the researchers, one covering socio-demographic characteristics with five questions related to age, gender, time in which they received the news of cancer, the responsible person who gave the news and type of cancer under treatment; and the second 
questionnaire covering the main objective of the study, through the question: "What did you feel at the time you received the news that you had cancer?".

The interviews were written. The work was approved by the Research Ethics Committee of the Padre Anchieta University Center and registered under the number: $1,214,726$.

According to the guidelines of the collective subject discourse, three methodological figures were adopted: Key Expressions, Central Ideas and Discourse of the Collective

For the treatment and analysis of the data, the following sequence was strictly followed: [13].

At the 1st stage: before starting copying the data, the answers were read several times to obtain a panoramic idea and a better understanding of the texts. Subsequently, the participants' answers were copied verbatim to the tool for Analysis of the Discourse 1. In the 2nd stage, the transcribed material was thoroughly read. In the 3rd step, all answers were analyzed to identify the Key Expressions, which were italicized. Having highlighted the Key Expressions and read them, the Central Idea of each subject studied was identified, with care to make it represent the description of the Key Expressions and not their interpretation. This same procedure was performed with the other answers, until the last one. In the 4th stage, the Tool for Analysis of the Discourse 2 was developed, containing each central idea with its respective similar or complementary Key Expressions. In the 5th stage, the theme of each interview question was grouped into their respective Central Ideas, as well as the participants, establishing the absolute and relative frequencies of ideas, organizing them.

\section{Results}

\subsection{Socio-demographic Characteristics of Respondents}

The majority of the participants are female $22(73.3 \%)$, over 43 years of age $20(66.7 \%)$. Regarding the time they received the news, in 26 cases $(86.6 \%)$, this happened in the last five years and the physician was the professional who disclosed the news 29 (97\%). The majority 19 (63.3\%) were undergoing cancer related to the thoracic area, mostly lung cancer.

Table 1. Socio-Demographic Characteristics of Users. Jundiai/SP. Brazil. $n=30$.

\begin{tabular}{lll}
\hline Socio-demographic characteristics & $\mathbf{N}^{\circ}$ & $\mathbf{( \% )}$ \\
\hline Age group & & \\
Up to 30 years & 2 & $6.6 \%$ \\
$\begin{array}{l}\text { From } 31 \text { to 36 years } \\
\text { From 37 to 43 years }\end{array}$ & 2 & $6.6 \%$ \\
More than 43 years & 6 & $20 \%$ \\
Gender & 20 & $66.6 \%$ \\
$\begin{array}{l}\text { Female } \\
\text { Male }\end{array}$ & 22 & $73.3 \%$ \\
$\begin{array}{l}\text { When person received the news } \\
\text { From 3 to 11 months ago }\end{array}$ & 8 & $26.6 \%$ \\
$\begin{array}{l}\text { From 1 to 5 years ago } \\
\text { How did the person receive the news? }\end{array}$ & 4 & $13.3 \%$ \\
\hline
\end{tabular}

\begin{tabular}{lll}
\hline Socio-demographic characteristics & $\mathbf{N}^{\circ}$ & $\mathbf{( \% )}$ \\
\hline From the physician & 29 & $96.6 \%$ \\
Alone & 1 & $3.3 \%$ \\
Type of cancer & & \\
Head/neck & 8 & $26.6 \%$ \\
Thorax & 19 & $63.3 \%$ \\
Abdomen & 4 & $13.3 \%$ \\
\hline
\end{tabular}

\subsection{Central Ideas of Respondents}

The central ideas and the respective frequency of occurrence related to the feelings at the moment the participants received the news of the cancer were: "fear" 9 (30\%); "sadness" 8 (26.6\%); "death" 5 (16.7\%); "normal" 3 (10\%); "guilt" 2 (6.6\%); "fright" 2 (6.6\%) and "suicide" 1 $(3.3 \%)$.

Table 2. Central Ideas, Participants and Frequency of Users Regarding the Feelings at Disclosure of Cancer Diagnosis. Jundiai/SP. Brazil. $n=30$.

\begin{tabular}{lll}
\hline Central Ideas & Participants & Frequency \\
\hline Fear & $6 ; 17 ; 19 ; 22 ; 24 ; 25 ; 26 ; 28 ; 29$ & $30 \%$ \\
Sadness & $3 ; 4 ; 10 ; 13 ; 16 ; 18 ; 20 ; 21$ & $26,6 \%$ \\
Death & $1 ; 5 ; 12 ; 14 ; 15$ & $16,6 \%$ \\
Normal & $7 ; 9 ; 11$ & $10 \%$ \\
Guilt & $27 ; 30$ & $6,6 \%$ \\
Shock & $8 ; 23$ & $6,6 \%$ \\
Suicide & 2 & $3,3 \%$ \\
\hline
\end{tabular}

\section{Discussion}

\subsection{Fear}

"I felt very scared, desperate, anguished, I could not understand why, I felt lost, I was afraid the treatment would not work and the discomfort of losing my hair with the treatment".

Fear of such a dreaded diagnosis is one of the conditions that cause patients to lose balance in all respects whether psychic or spiritual [14].

Even though chances of cure are much greater now than in past times, women with cancer nowadays fear the aesthetic consequences of the treatment, including alopecia and surgical scars, despite the many alternatives to mask the effects of the treatment and face the situation in the aspect of self-image [15].

Time has passed, treatments have evolved and values have changed, but the fragility before cancer is immense [14].

\subsection{Sadness}

"I was sad, I told myself it was the worst, I felt a great anguish, I cried a lot, it knocked me over".

The discourses regarding the disclosure of diagnosis were permeated by an intense emotional component, described as a unique, shocking, traumatic and desperate experience, as if it were the worst possible feeling to be felt [16].

Everything that is within the reach of ideas brings even more sadness, such as thinking on family members and children and how this disease can affect all of them, leads in the first moment to hopelessness, because the family also participates in the process, and the evolution of feelings is 
collective and the support from the family is essential [17].

\subsection{Death}

"I felt very scared, desperate, anguished, I could not understand why, I felt lost, I was afraid the treatment would not work and the discomfort of losing my hair with the treatment".

Historically, cancer is seen as a disease which inevitably leads to death. Despite the huge advances in medicine in recent decades in relation to the treatment of cancer, such as procedures and pharmacological and the advent of radiotherapy, it still carries the stigma of fatal disease.

The idea of the possibility of eminent death involves innumerable problems of a clinical, ethical, social, psychological and familial nature contained in the possibility of terminality, with immeasurable feelings [18].

Death is not yet seen as a natural phenomenon in western culture, but rather as a fearsome event, an incident to be avoided at all costs.

\subsection{Normal}

"I felt normal, not scared, the doctor said it was not one of the most aggressive, so I faced the disease without fear".

Some people have the calmness or strength necessary to face a cancer diagnosis as a normal thing. This strength is characterized by the ability to face a disease that in our culture is synonymous with death and is followed by the pain of an extremely aggressive treatment [19].

\subsection{Guilt}

"I blame myself for smoking and because I did not do the exams regularly".

The feeling of guilt is common among patients who have developed cancer because they have certain addictions and/or bad habits, and did not perform routine and preventive laboratory tests they were instructed to do. However, this feeling mostly happens in the first moments, when denial is intense [20, 21].

Patients do not know exactly what to do about this situation, since they have experienced significant personal and family disruption. The disease represents patients a journey, that is, the beginning of a long treatment and with many reactions such as hair loss, pain among other factors. This is a scare, a surprise, because with the diagnosis given it is understood that either it does the treatment even with these reactions or the disease advances.

\subsection{Shock}

"It was a blow, a shock, it seems like the world is over".

Almost all patients report the same sensations. Shock predominates in the social impact, because the news is never expected, and it always puts to test the ideas that the patient has in relation to the future. A swirl of emotions can be used to describe the sensation of shock [22].

Patients do not know exactly what to do about this situation, since they have experienced significant personal and family disruption. The disease represents patients a journey, that is, the beginning of a long treatment and with many reactions such as hair loss, pain among other factors. This is a scare, a surprise, because with the diagnosis given it is understood that either it does the treatment even with these reactions or the disease advances.

\subsection{Suicide}

"The initial feeling was devastating and disorienting, making me feels like throwing myself under the first car, the feeling that everything in life had lost purpose, I felt lost, there was an immediate idea of suicide, of imminent death".

The diagnosis of cancer has consistently been associated with several mental disorders that can boost self-destructive tendencies and, in the limit, lead to suicide [23].

Some research studies have claimed that there are high levels of suicide among cancer patients, as a desperate attitude of giving up a fight against a progressive disease that has no prognosis. However there is a hypothesis that the diagnosis of cancer can trigger immediate adverse consequences also to mental health, besides the effects of the disease and treatment [24].

Suicide can be a means of maintaining control and a comforting alternative for patients who are overwhelmed by uncertainty, feelings of helplessness and fear of experiencing unbearable suffering [23].

\section{Conclusion}

The central ideas, for the most part, showed that feelings of fear, hopelessness, and even perceptions of death emerge at the moment of disclosure of diagnosis, regardless of the type of cancer. Cancer diagnosis carries with it a variety of confusing feelings, difficult to understand, not only for the patient, but also for family members and friends who have difficulty coping with the fact that a loved one is suffering from this disease.

There is no right or wrong way to behave in this situation. Patients, friends and family members little by little find the best way to express themselves more calmly about the disease.

Sincere conversation is always recommended and considered a very important step at that time. On the other hand, we emphasize the little attention focused on the training for skills and communication techniques, which makes professionals often rely on their personal experiences and judgments to decide how to inform the patients about their illness. There is a lack of preparation on the part of some professionals that leaves patients aside not only regarding the diagnosis, but also regarding their right of choice before therapeutic possibilities or palliative care groups that can provide a better quality of life.

It is recommendable that researches such as the present one portraying the patients' perceptions at disclosure of cancer diagnosis be carried out and disseminated in the scientific environment, to serve as a basis for discussions and reflections among all professionals involved in this endeavor, 
which is to give such shocking news surrounded by much stigma.

\section{References}

[1] Instituto Nacional de Câncer José De Alencar Gomes da silva. 2015. [ONLINE]. Available at:

http://www1.inca.gov.br/conteudo_view.asp?id=322.

[Accessed 03 August 2016].

[2] Instituto Oncoguia 2015. Available at: http://www.oncoguia. org.br/conteudo/causas-do-cancer/80/1. [Accessed 06 July 2016].

[3] Facina T. Estimativa 2014: Incidência de Câncer no Brasil. Rev Bras de Cancerol. 2014; 60(1): 63.

[4] Pedro ICS and Rocha SMM, Nascimento LC. Apoio e rede social em enfermagem familiar revendo conceitos. Rev Latino-am Enfermagem 2008; 16(2): 324-27.

[5] Silva MJP and Araújo MMT. Comunicação em cuidados paliativos. In: Academia Nacional de Cuidados Paliativos. Manual de Cuidados Paliativos. Rio de Janeiro: Dia Grafic; 2009. p. 49-57.

[6] Araujo JÁ and Leitão EMP. A comunicação de más notícias: mentira piedosa ou sinceridade cuidadosa. Revista Hospital Universitário Pedro Ernesto. 2012; 11(2):58-62.

[7] Brasil. Ministério da Saúde. Instituto Nacional de Câncer (INCA). Comunicação de notícias difíceis: compartilhando desafios na atenção à saúde. Rio de Janeiro: INCA, 2010.

[8] Nonino A, Magalhães SG and Falcão DP. Medical Training for Breaking Bad News: Review of the Literature. Revista Bras de Educação Médica. 2012, 36 (2): 228-233.

[9] Jodelet D. La representación social: fenómenos, concepto y teoria. In: Moscovici. Psicologia Social. Barcelona: Paidós; 1985. v. 2, p. 469-94.

[10] Arruda A. Representações Sociais: emergência e conflitos na psicologia social. In: Batista LAS (org.). Anuário do laboratório de subjetividade política. 1991-1992; 1 (1): p. 11531 .

[11] Jodelet D. Representations Sociales: undomaineen expansion. In: Jodelet D. Les representaciones sociales. Paris: Presses Universitales de France; 1989.

[12] Sawaia BB. Representação e ideologia: o encontro desfetichizador. In: Spink MJP (org.). O conhecimento no cotidiano: as representações sociais na perspectiva da Psicologia Social. São Paulo: Brasiliense; 1995.p. 73-84.
[13] Lefèvre F, Lefèvre AMC and Teixeira JJV, (org.). O Discurso do Sujeito Coletivo. São Paulo: EDUCS; 2000.

[14] Regis MF and Simões MF. Diagnóstico de câncer de mama, sentimentos, comportamentos e expectativas de mulheres. Rev Eletr Enfer, 1 (07), p. 81 - 86, 2005. Available at: https://www.fen.ufg.br/fen revista/revista7 1/original 08.htm. [acessado em 06 Nov 2015].

[15] Caetano EA, Gradim CVC and Santos LES. Câncer de mama: reações e enfrentamento ao receber o diagnostico. Rev. enferm. UERJ, Rio de Janeiro, 2009 abr/jun; 17(2):257-61.

[16] Beltrão MRLR, Vasconcelos MGL, Pontes CM and Albuquerque MC. Câncer infantil: percepções maternas e estratégias de enfrentamento frente ao diagnostico. J Pediatr (Rio J). 2007; 83(6):562-566.

[17] Alegrance FC, Souza CB and Mazzei RL. Qualidade de vida e estratégias de enfrentamento em mulheres com e sem linfedema pós-câncer de mama. Rev Bras de Cancerol 2010; 56(3): 341-351.

[18] Borges ADVS, Silva EF, Toniollo PB, Mazer SM, Valle ERM and Santos MA. Percepção da morte pelo paciente oncológico ao longo do desenvolvimento. Psicol em Estud, Maringá. 2006. 11(2): 361-369, mai./ago.

[19] Menezes NNT, Schulz VL and Peres RS. Impacto psicológico do diagnóstico do câncer de mama: um estudo a partir dos relatos de pacientes em um grupo de apoio. Estudos de Psicologia, 2012. 17(2): 233-240.

[20] Galvan DC, Kaufmann G, Brustolin AM, Ascari RA. Percepção dos pacientes acometidos pela leucemia frente a internação hospitalar. Rev Enferm UFSM 2013; 3(Esp.):647657.

[21] Silva G and Santos MA. Estressores pós-tratamento do câncer de mama um enfoque qualitativo. Rev. Latino-Am. Enferm. 2010; 18(4):[08 telas] jul-ago.

[22] Caetano EA, Gradim CVC and Santos LES. Câncer de mama: reações e enfrentamento ao receber o diagnóstico. Revista de Enfermagem da UERJ, 2009; 17(2), 257-261.

[23] Santos MA. Cancer and suicide among the elderly: psychosocial determinants of risks, psychopathology and opportunities for prevention. Ciência \& Saúde Coletiva, 2017; 22(9):3061-3075.

[24] Fang F, Fall K, Mittleman MA, Sparén P, Ye W, Adami HO et al. Suicide and cardiovascular death after a cancer diagnosis. N Engl J Med 2012; 366(14):1310-18. 